\title{
Diversity of cetaceans as tool in monitoring environmental impacts of seismic surveys
}

\author{
Cristiano Leite Parente ${ }^{1,2}$, Janaína Pauline de Araújo $^{I}$ \& Maria Elisabeth de Araújo ${ }^{1}$ \\ Biota Neotropica $v 7(n 1)$ \\ http://www.biotaneotropica.org.br/v7n1/pt/abstract?taxonomic-review +bn01307012007 \\ Data Received 09/08/06 \\ Revised 26/12/06 \\ Accepted 21/02/06 \\ ${ }^{1}$ Universidade Federal de Pernambuco, Programa de Pós-Graduação em Oceanografia, \\ Departamento de Oceanografia, Av. Prof. Moraes Rego, 1235, Cidade Universitária, \\ Recife, Pernambuco, CEP 50670-901, Brazil \\ ${ }^{1,2}$ Corresponding author: Cristiano Leite Parente, e-mail: cristiano.parente@uol.com.br
}

\begin{abstract}
Parente, C.L., Araújo, J.P. \& Araújo, M.E. Diversity of cetaceans as tool in monitoring environmental impacts of seismic surveys. Biota Neotrop. Jan/Apr 2007 vol. 7, no.1 http://www.biotaneotropica.org.br/v7n1/ pt/abstract?article+bn01307012007 ISSN 1676-0603.

New information about the effects of seismic surveys on cetaceans is causing increasing concern about the impact of this type of activity on marine life. The effects described include behavioral responses and changes in vocalization patterns, diversion of migratory routes, damage to the auditory system, and an increase in strandings. Although such effects could affect the diversity of species in areas where seismic research has been carried out, there is no scientific information on this subject. This study aims to evaluate the relationship between seismic surveys, oceanographic data and diversity of cetaceans recorded in Brazil following the stepping up of seismic survey activities between 1999 and 2004. The study is based on oceanographic data from the Pilot Research Moored Array in the Tropical Atlantic (PIRATA Project), sightings made during seismic surveys, progress reports from Brazilian research projects to the International Whaling Commission, Brazilian seismic survey reports available at the Escritório de Licenciamento de Petróleo e Nuclear of the Instituto Brasileiro do Meio Ambiente e dos Recursos Naturais Renováveis (ELPN-Ibama) and complementary data from the webpage of the Agencia Nacional de Petróleo e Gás Natural (ANP). The results suggest a decrease in the diversity of species in the face of an increase in the number of seismic surveys during the years 2000 and 2001, even though there was no significant change in oceanographic patterns in this period, and that a relationship exists between diversity of cetaceans and intensity of seismic surveys between 1999 and 2004. It is recommended that data collection be improved in order to evaluate this hypothesis properly. The results suggest that species diversity might be used as a long-term indicator of the impact of seismic surveys on cetaceans.
\end{abstract}

Keywords: noise impact, seismic survey, diversity of cetaceans, South America.

\section{Resumo}

Parente, C.L., Araújo, J.P. \& Araújo, M.E. Diversidade de cetáceos como ferramenta no monitoramento dos impactos ambientais das sísmicas marítimas. Biota Neotrop. Jan/Apr 2007 vol. 7, no. 1 http://www.biotaneotropica.org.br/v7n1/pt/abstract?article+bn01307012007 ISSN 1676-0603.

Tem sido constante o surgimento de novas informações sobre o efeito das sísmicas marítimas em cetáceos, demonstrando uma crescente preocupação com essa atividade. Os efeitos da atividade incluem respostas comportamentais e mudanças nos padrões de vocalização, alterações nas rotas migratórias, danos no sistema auditivo e aumento dos encalhes. Embora todos esses efeitos possam afetar a diversidade de espécies nas áreas de realização de sísmicas marítimas, não existem informações acadêmicas nesse sentido. Este estudo buscou verificar as relações entre as sísmicas marítimas, dados oceanográficos e a diversidade de cetáceos registrados no Brasil após a intensificação das operações a partir de 1999 até o ano 2004. Foram utilizados dados de observações de cetáceos realizadas durante as sísmicas marítimas e complementadas por relatórios de progresso do Brasil enviados para a Comissão Internacional Baleeira, dados oceanográficos disponibilizados pelo projeto Pilot Research Moored Array in the Tropical Atlantic (PIRATA) e informações de sísmicas marítimas arquivadas no Escritório de Licenciamento de Petróleo e Nuclear do Instituto Brasileiro do Meio Ambiente e dos Recursos Naturais Sustentáveis (ELPN-Ibama) e outras disponibilizadas na página da Internet da Agencia Nacional de Petróleo e Gás Natural (ANP). Os resultados indicam decréscimo na diversidade de espécies durante os anos 2000 e 2001, enquanto uma intensificação das sísmicas marítimas foi registrada para os mesmos anos. Os dados oceanográficos não apresentaram variações significativas entre os anos estudados. Os resultados sugerem alguma relação de efeito e causa entre a diversidade de cetáceos e a intensidade de sísmicas marítimas ocorridas no Brasil entre 1999 e 2004. O aprimoramento na coleta de dados com foco mais específico para avaliar os efeitos imediatos 
na diversidade é recomendado para melhor avaliação da hipótese e utilização da diversidade de espécies como

indicador de longo prazo dos impactos das sísmicas marítimas nos cetáceos.

Palavras-chave: impacto sonoro, sísmica marítima, diversidade de cetáceos, América do Sul.

\section{Introduction}

Although new species are recorded from time to time, there are, at present, only 119 identified species of aquatic mammals throughout the world (Jefferson et al. 1994). The order Cetacea contains 84 of those species, which inhabit oceans, rivers and estuaries and, of these, 13 belong to the Mysticeti sub-order, and 71 to the Odontoceti. Brazilian waters host 43 species of cetaceans: 8 species of Mysticeti and 35 species of Odontoceti (Instituto Brasileiro do Meio Ambiente e dos Recursos Naturais Renováveis - IBAMA 2001, Pinedo et al. 2002).

In Brazil, as in other parts of the world, these aquatic mammals are negatively impacted by a number of human activities, such as fishing (e.g. Monteiro-Neto et al. 2000, Pizzorno et al. 1998, Siciliano 1994), tourism (e.g. Lodi et al. 1996, Silva Jr. 1996) and industrial activities. More recently, it has been suggested that the stranding of adult male humpback whales is associated with seismic surveys in the Northeast region of Brazil (Engel et al. 2004). Concern as to the effects of seismic surveys on marine mammals is not recent (e.g. Green et al. 1994, Popper et al. 2000, Richardson et al. 1995). Some studies have demonstrated that noise emitted by seismic survey air-guns causes differing effects on different species of cetaceans due to: hearing sensitivity, behavior, habituation or desensitization, age, sex, location of exposure, and proximity to a shoreline (e.g. Dolman \& Simmonds 2003, Evans et al. 1993, Gordon et al. 2004, Madsen et al. 2002). Recently, a study off Scotland has suggested that the absence of certain whale species from one sea area surveyed in 1998, where they might be expected to have been found, may have resulted from the incidence of seismic survey work there, although other potentially confounding variables are also noted (MacLeod et al., in press). Nonetheless, the available information focuses only on a small number of species that are observed in the course of a seismic survey or that are already undergoing observation (e.g. Goold 1996, Mate et al. 1994, McCauley et al. 2000) and it is not acceptable to extrapolate the results obtained for some species to others due to the variation in the acoustic characteristics of the environment and the potential differences in sensitivity between the animals.

Species diversity has proven to be an excellent tool for the analysis of environmental impacts (e.g. Myers 1989, Gaston 2000, Weitzman 1993). However, variation in cetacean diversity measured using diversity indexes in the light of oceanographic patterns and the presence of seismic surveys in the area has not yet been verified. There are a number of explanations for the lack of such studies, including: 1) the difficulty of undertaking a long-term series of observations of marine mammals using standardized procedures, and 2) the fact that research into cetaceans normally focuses on the most common species in certain areas. Given the variations in cetacean behavior responses to seismic surveys, it is possible that the diversity of species in a certain area could be altered because of the oceanographic patterns or the presence of seismic surveys over large areas. This research aims to evaluate the potentiality to use the diversity of cetaceans as tool to indicate effects of the seismic surveys in this group of animals recorded in the Brazilian ocean shelf between 1999 and 2004.

\section{Materials and Methods}

\section{Data sources}

Information on the diversity of cetaceans in Brazil was obtained from two sources: the Brazilian progress reports published by the International Whaling Commission (IWC) between 1999 and 2004 (IWC 2005), which are compiled annually by the Brazilian government on the basis of the results of those involved in research into and conservation of cetaceans in the country, and from reports of sightings during seismic surveys over the same period and available in the archives of the ELPN (Escritório de Licenciamento de Petróleo e Gás Natural). Cetacean records were obtained by researchers by way of sightings surveys and monitoring along the whole coastline of Brazil. As data originated from different institutions and researchers lacked standardized procedures and sampling methods, the study was restricted to the presence or absence of species in Brazil to cluster analyses, and number of specimens to diversity analyses. Even though this methodology is uncommon in studies of cetaceans, it is recommended by biologists as an effective tool for ecological studies (Legendre \& Legendre 1998). The period interval of data between 1999 and 2004 was selected because it coincides with recent seismic surveys and research on cetaceans has increased since 1997, when the Brazilian government published the first Action Plan about Marine Mammals (IBAMA 1997), insuring that changes in diversity were not the result of changes in research efforts.

The data on seismic surveys carried out between 1999 and 2004 were taken from annual reports of the ANP (Agência Nacional do Petróleo e Gás Natural 2005) and supplemented with reports from the ELPN. The information on 2-dimensional (2D) and 3-dimensional (3D) seismic surveys was organized in an electronic database - allowing for evaluation of the evolution of seismic surveys during the period in terms of the technology used.

The information concerning oceanographic parameters (temperature, salinity and density) was obtained during seismic surveys and from the PIRATA (Pilot Research Moored Array in the Tropical Atlantic) which was downloaded from the website of the TAO Project (Tropical Atmosphere Ocean project). Data from this project was used to calculate the monthly mean temperature $\left({ }^{\circ} \mathrm{C}\right)$, salinity (PSU) and density $\left(\mathrm{kg} / \mathrm{m}^{3}\right)$ to a depth of $1 \mathrm{~m}$ from the buoy sited at $10^{\circ} \mathrm{S}-10^{\circ} \mathrm{W}$.

\subsection{Analysis of data}

The information about cetaceans was organized in an electronic database in order to draw up an annual table of presence and absence of cetacean species in Brazilian waters. This table enabled quantification of the number of cetacean species recorded throughout the period studied, and application of the Shannon-Wiener diversity index ( $\left.\mathrm{H}^{\prime}\right)$, based on Log2 (Shannon 1948).

The tables with the annual list of species (presence/absence), oceanographic data and annual seismic surveys were submitted to cluster analyses using the weighted pair-group method, and arithmetic average (WPGMA) in Q modules to verify levels of similarity across the years studied (Legendre \& Legendre 1998). The Dice coefficient was used for the cetacean species tables and the Euclidean distances coefficient was applied to the seismic surveys and oceanographic data tables. A cophenetic analysis was also carried out to test the 
goodness of fit of clustering to the set of data (Dice 1945, Legendre \& Legendre 1998, Rohlf \& Fisher 1968).

The Kruskal-Wallis non-parametric statistical test was applied to the number of seismic surveys being carried out by month to verify significant differences over the years as well as to analyze the differences in the oceanographic parameters over the same period. To compare the variance of the oceanographic data, the ANOVA test was applied to the matrix of each parameter (temperature, salinity, and density).

The means of seismic surveys/month and the diversity indexes of cetaceans by years were submitted to the non-parametric statistical test of Spearman to verify their level of correlation. Results of $\mathrm{p} \leq 0.05$ were taken to be statistically significant for the tests as a whole.

\section{Results}

\subsection{Seismic surveys}

A total of 103 seismic surveys were carried out over the period, corresponding to 21 seismic programs using the technology for 2dimensions (2D), covering 300,388.7 km, and 82 using technology for 3 -dimensions (3D), covering 162,494.1 km². The number of seismic surveys in operation/month was highest in 2000 with 43 programs $($ mean $=15.2$ survey/month; SD = 3.4), followed by $2001(\mathrm{n}=27$; mean $=9.6 ; \mathrm{SD}=7.1), 2002(\mathrm{n}=24 ;$ mean $=6.0 ; \mathrm{SD}=1.1), 2003$ $(\mathrm{n}=20 ;$ mean $=2.8 ; \mathrm{SD}=1.4), 1999(\mathrm{n}=13 ;$ mean $=6.7 ; \mathrm{SD}=5.9)$ and $2004(\mathrm{n}=13$; mean $=2.1 ; \mathrm{SD}=1.4)$. (Figure 1$)$ shows the distribution of the seismic surveys over the years.

The cluster analysis of the number of seismic surveys in operation/month in each year showed a great similarity between the years 2000 and 2001 compared to other years studied (Figure 2), further confirming the intensification of seismic surveys in those years. The cophenetic analysis showed a good fit of the data, explaining more than $90 \%$ of possible variations $(\lambda=0.90372)$. The Kruskal-Whallis statistical test also showed very significant differences between the years 2000 and 2001 and the others $(H=35.74 ; p=0.000000)$.

\subsection{Diversity of cetaceans}

Of the 43 species of cetaceans occurring in Brazil, 33 (76.7\%) were recorded between the years 1999 and 2004 (Table 1). These included the following families: Balaenidae, Balaenopteridae, Delphinidae, Kogiidae, Phocoenidae, Physeteridae, Pontoporiidae, and Ziphiidae. The cetaceans that were not identified to the taxonomic level of species were not considered.

The number of species varied over the years and among regions as can be observed in Figure 1. The Delphinidae family was mainly
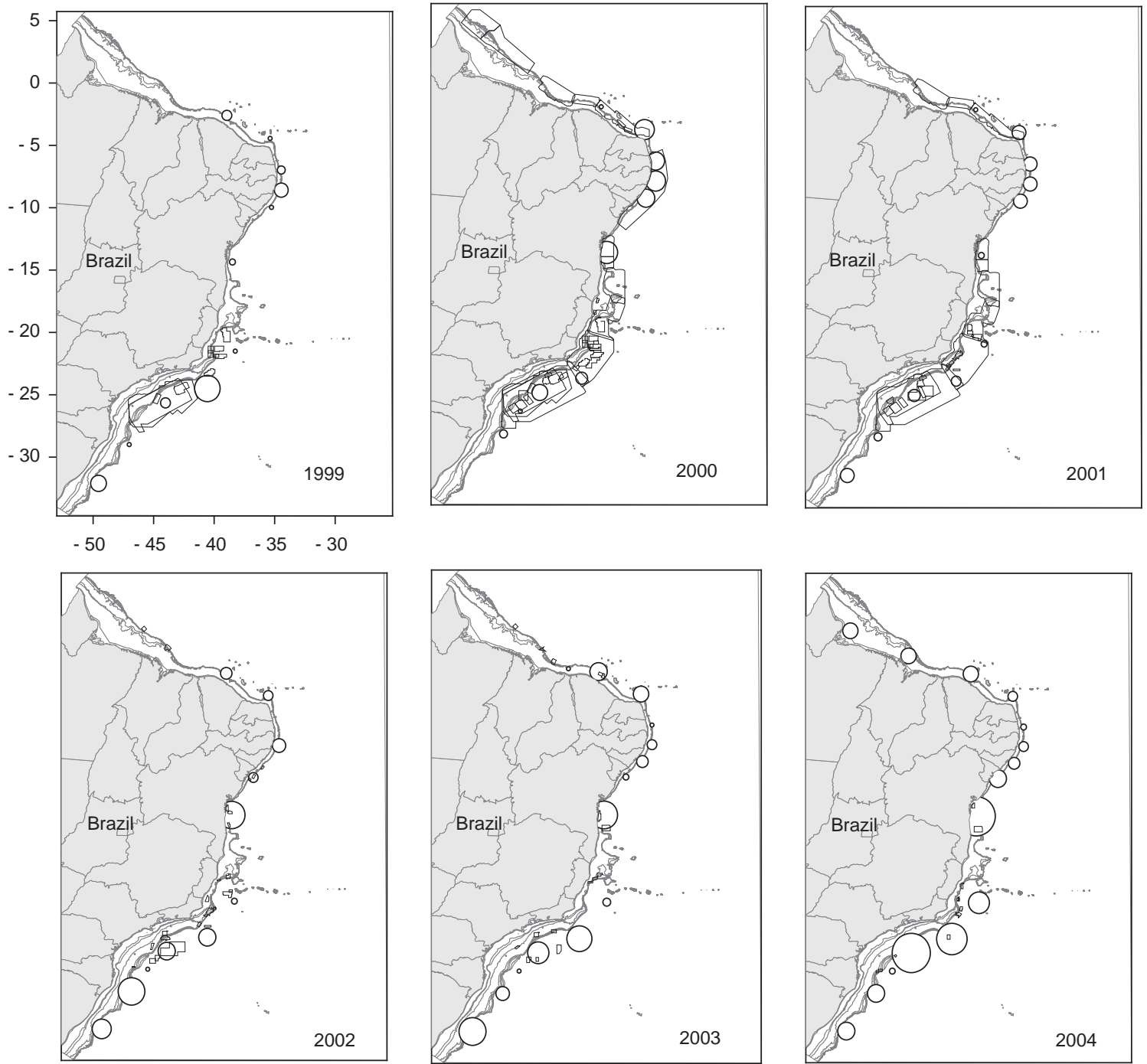

Figure 1. Areas where seismic surveys (black) were carried out in Brazil between 1999 to 2004 and volume of diversity of cetaceans (white).

Figura 1. Áreas de ocorrência de sísmicas marítimas (preto) entre 1999 e 2004 e quantidade de diversidade de cetáceos (branco). 
responsible for the reduction in the total number of species recorded during the years 2000 and 2001. The cluster analysis of the species present and absent for each year, including species identified at genus level, showed a great similarity between the years 2000 and 2001 compared to the other years studied (Figure 3), as was the case with the analysis of seismic surveys. The cophenetic analysis showed a good fit of the data $(\lambda=0.83396)$ (Rohlf $\&$ Fisher 1968).

The Shannon-Wiener diversity indexes for the studied period were: $\mathrm{H}^{\prime}=3.178$ bits.indiv. $^{-1}$ in $1999, \mathrm{H}^{\prime}=2.996$ bits.indiv. $^{-1}$ in $2000, \mathrm{H}^{\prime}=2.565$ bits.indiv $^{-1}$ in $2001, \mathrm{H}^{\prime}=3.296$ bits.indiv. $^{-1}$ in 2002 , $H^{\prime}=3.401$ bits.indiv. $^{-1}$ in 2003 , and $H^{\prime}=3.497$ bits.indiv $^{-1}$ in 2004. These indexes showed a slight variation in the diversity of species over the years with a reduction in the years 2000 and 2001. When those diversity indexes were submitted to Spearman test together the means of seismic surveys/month of each year the result was significant $\left(\mathrm{r}_{5}=-0.9429 ; \mathrm{t}=-5.9565 ; \mathrm{p}=0.0048\right)$ and shown a negative correlation.

\subsection{Oceanographic parameters}

The mean of temperature, salinity and density of water at the point analyzed did not show great variation over the years (Figure 4). The temperature varied from $23.13^{\circ} \mathrm{C}$ to $27.35^{\circ} \mathrm{C}$, salin-

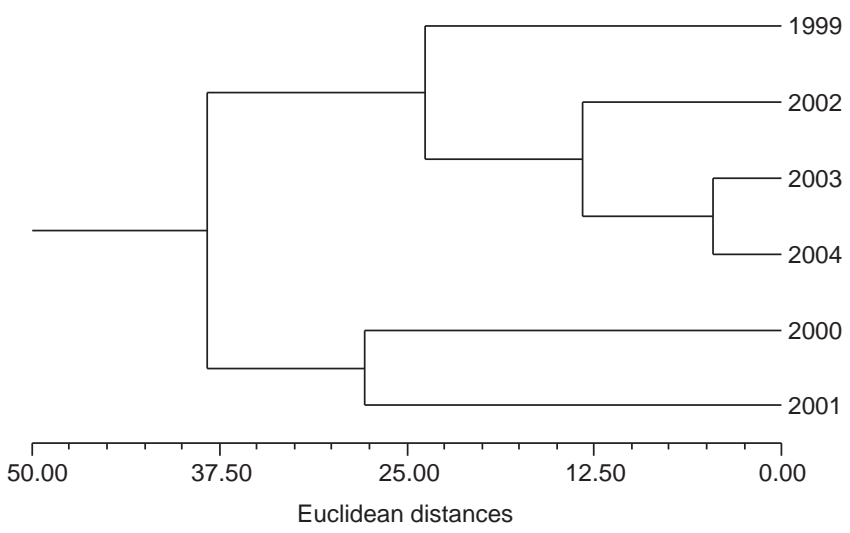

Figure 2. Tree data structure of the clustering analyses of the years by number of seismic surveys carried out $(\lambda=0.90372)$.

Figura 2. Dendrograma em modo Q do número de sísmicas marítimas realizadas por ano $(\lambda=0.90372)$.

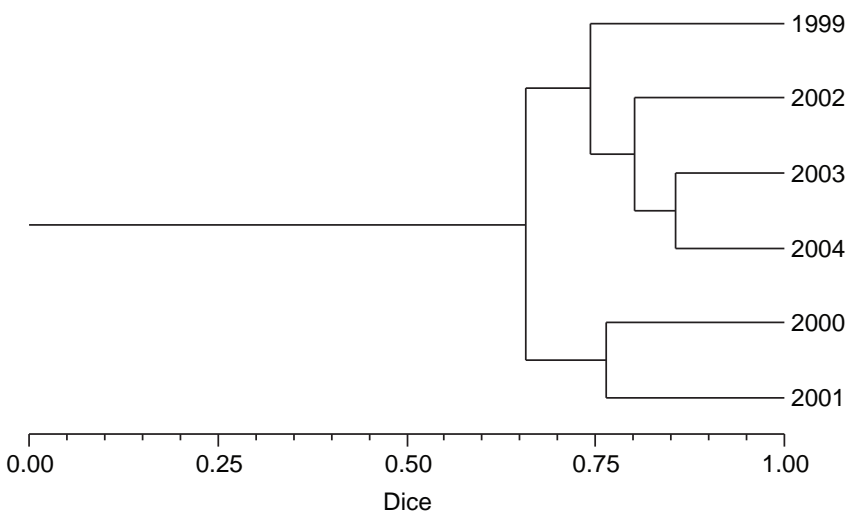

Figure 3. Tree data structure of the cluster analyses grouping the years studied by similarity in terms of the presence and absence of cetacean species $(\lambda=0.83396)$.

Figura 3. Dendrograma em modo $Q$ da presença e ausência de espécies de cetáceos por ano $(\lambda=0.83396)$. ity from 36.0 to $36.6 \mathrm{PSU}$, and density from 23.5 to $25.0 \mathrm{~kg} / \mathrm{m}^{3}$. The ANOVA Statistical test showed that variations were not significant for the three parameters: temperature $(\mathrm{F}=0.1385 ; \mathrm{p}=0.9807)$, salinity $(\mathrm{F}=2.2347 ; \mathrm{p}=0.0604)$, and density $(\mathrm{F}=0.3261 ; \mathrm{p}=0.8954)$. The cluster analyses of the oceanographic parameters are presented in the (Figure 5). As the other information analyzed in this study, the cophenetic analysis of density, salinity and temperature showed a good fit

Table 1. List of cetacean species registered in Brazil between 1999 and 2004

\begin{tabular}{|c|}
\hline Taxonomy \\
\hline Mysticeti \\
\hline Balaenopteridae \\
\hline Balaenoptera acutorostrata Lacépède (1804) \\
\hline Balaenoptera bonaerensis Burmeister (1867) \\
\hline Balaenoptera borealis Lesson (1828) \\
\hline Balaenoptera edeni Anderson (1879) \\
\hline Balaenoptera physalus (Linnaeus 1758) \\
\hline Megaptera novaeangliae (Borowski 1781) \\
\hline Balaenidae \\
\hline Eubalaena australis Desmoulins 1822 \\
\hline Odontoceti \\
\hline Delphinidae \\
\hline Delphinus capensis Gray (1828) \\
\hline Delphinus delphis Linnaeus (1758) \\
\hline Feresa attenuata Gray (1874) \\
\hline Globicephala macrorhynchus Gray (1846) \\
\hline Globicephala melas (Traill 1809) \\
\hline Grampus griseus (Cuvier 1812) \\
\hline Lagenodelphis hosei Fraser (1956) \\
\hline Orcinus orca (Linnaeus 1758) \\
\hline Peponocephala electra (Gray 1846) \\
\hline Pseudorca crassidens (Owen 1846) \\
\hline Sotalia guianensis (van Bénéden 1864) \\
\hline Stenella attenuata (Gray 1846) \\
\hline Stenella clymene (Gray 1850) \\
\hline Stenella coeruleoalba (Meyer 1833) \\
\hline Stenella frontalis (Cuvier 1829) \\
\hline Stenella longirostris (Gray 1828) \\
\hline Steno bredanensis (Cuvier in Lesson 1828) \\
\hline Tursiops truncatus (Montagu 1821) \\
\hline Kogiidae \\
\hline Kogia breviceps (Blainville 1838) \\
\hline Kogia sima (Owen 1866) \\
\hline Pontoporidae \\
\hline Pontoporia blainvillei (Gervais \& d'Orbigny 1844) \\
\hline Phocoenidae \\
\hline Phocoena spinipinnis Burmeister (1865) \\
\hline Physeteridae \\
\hline Physeter macrocephalus Linnaeus (1758) \\
\hline Ziphiidae \\
\hline Berardius arnuxii Duvernoy (1851) \\
\hline Mesoplodon europaeus (Gervais 1855) \\
\hline Ziphius cavirostris Cuvier (1823) \\
\hline
\end{tabular}


of the data, explaining more than $80 \%$ of possible variations (Density $\lambda=0.85788$; Salinity $\lambda=0.86262$; Temperature $\lambda=0.84486)$.

\section{Discussion}

The pattern of seismic surveys occurring in Brazil agrees with the analyses carried out by Parente \& Araujo (2005), which recorded a rapid increase up to 2001, and a drop in the following years. The 2004 seismic surveys were similar those of 2002 and 2003 in terms of both their number and the technology used. The seismic surveys were widely spread out along Brazilian coast during 2000 and 2001. The predominant technology used in this period was the 2D-technology that covers large areas, while 3-D technology came to predominate after 2002 in restricted areas. The decline in activity in the last few
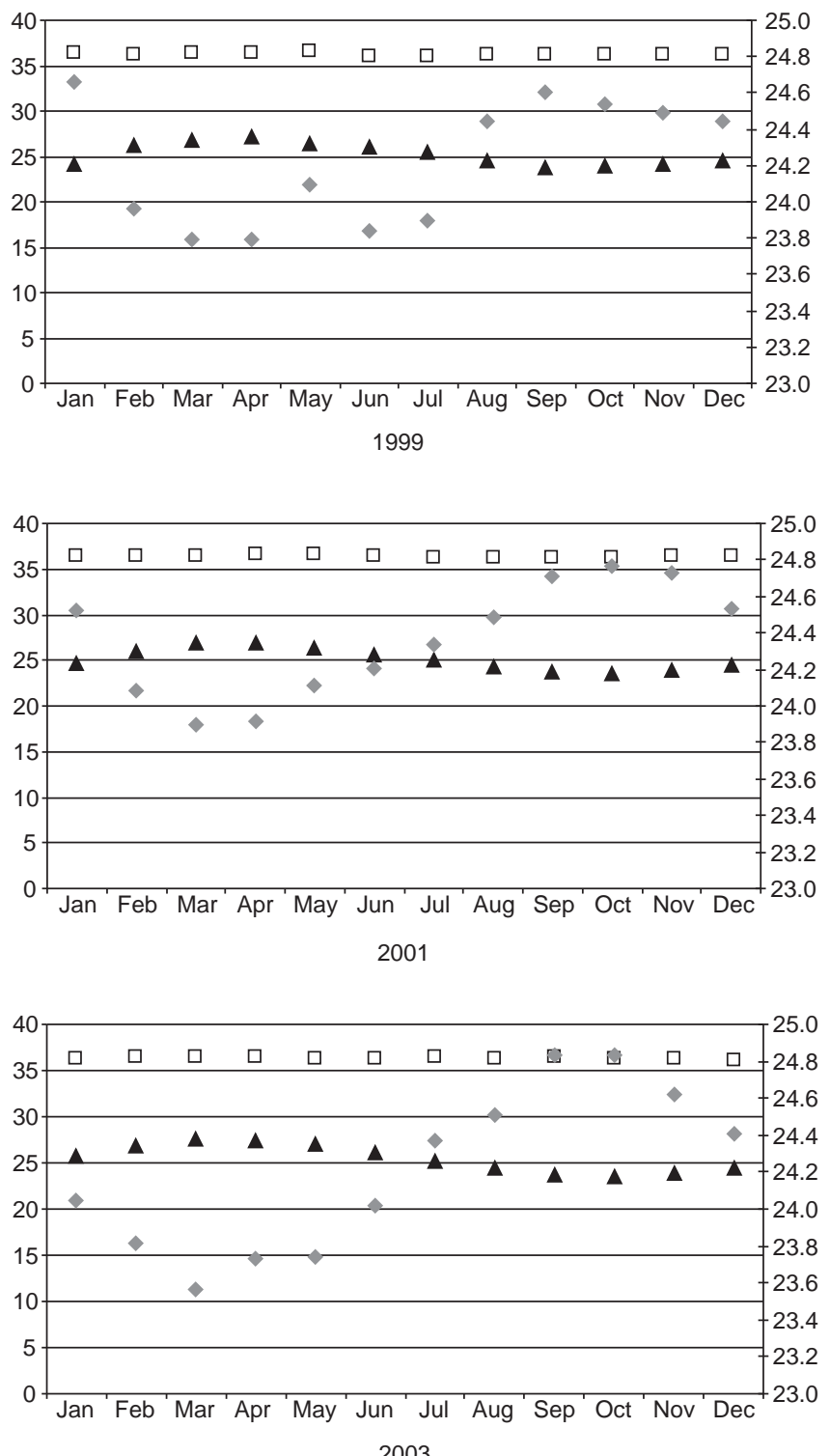

years resulted from a stricter policy being introduced by IBAMA and the end of the long period of exploration surveys using 2D-technology (Parente \& Araujo 2005).

The environmental control exercised by the Brazilian government includes defined periods and exclusion zones, as well as the requirement to carry out specific environmental studies according to the environmental sensitivity of each area (Vilardo et al. 2003). The first exclusion period/zone defined by IBAMA was the Abrolhos Bank during the winter, owing to its importance for the conservation of the humpback whale (Engel et al. 2004). This decision has been widely criticized by seismic contractors who believe it could reduce the development of the oil industry in Brazil. As petroleum accumulates in basins, the areas near the Abrolhos Bank may constitute a large reserve of this resource. This situation will require IBAMA and the
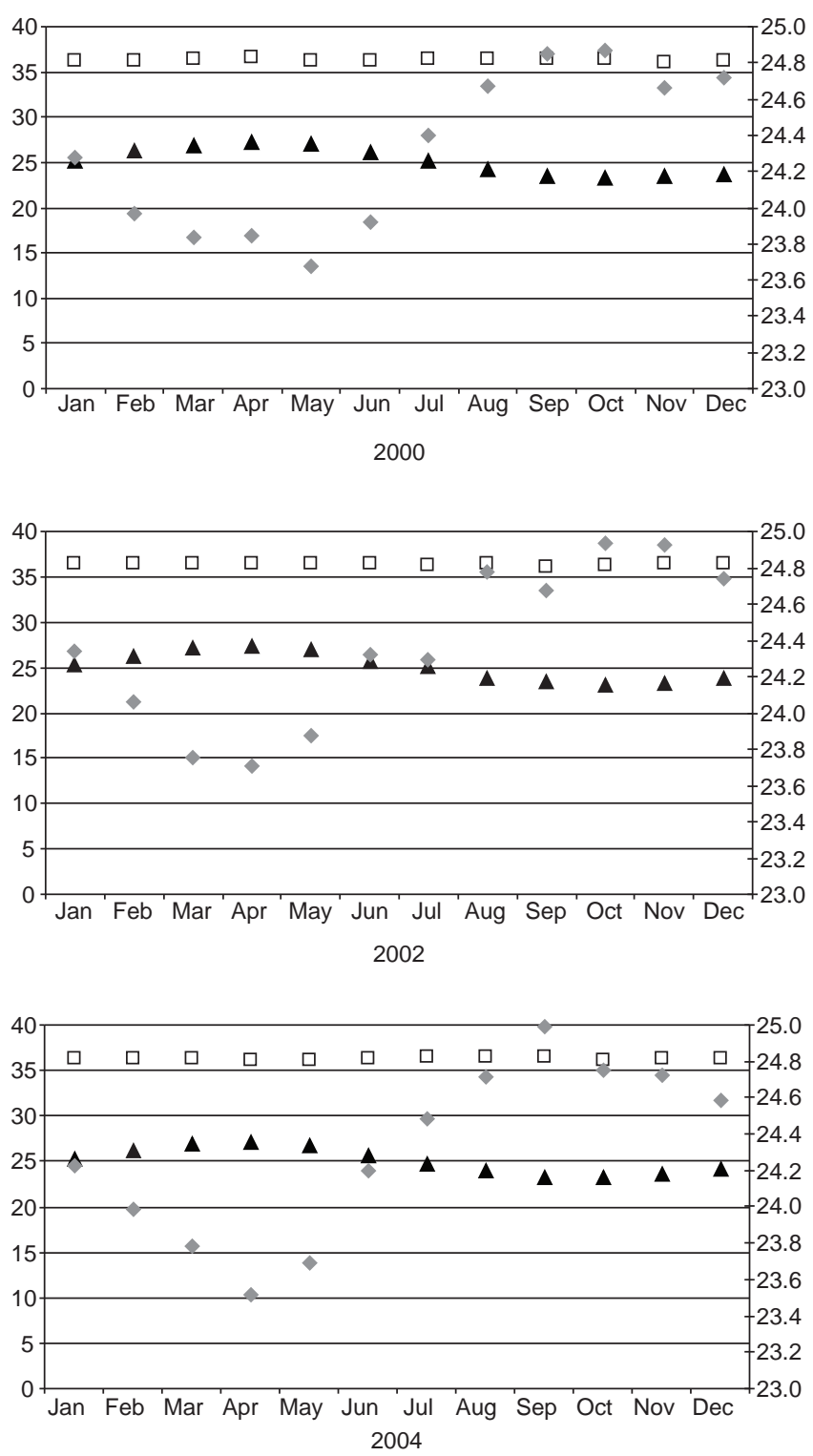

$\square$ Salinity (PSU) $\Delta$ Temperature $\left({ }^{\circ} \mathrm{C}\right) \diamond$ Density $\left(\mathrm{kg} / \mathrm{m}^{3}\right)$

Figure 4. Means for oceanographic parameters during seismic surveys and on the western rim of the Atlantic Ocean ( $\left.10^{\circ} \mathrm{S}-10^{\circ} \mathrm{W}\right)$ between 1999 and 2004 (Salinity - left, Temperature and Density - right).

Figura 4. Média dos parâmetros oceanográficos durante as sísmicas marítimas e na margem oeste do Oceano Atlântico (10 S-10 W) entre 1999 e 2004 (Salinidade - esquerda, Temperatura e Densidade - direita). 
oil industry to develop environmental management tools to exploit the area without interfering in the habitat of the humpback whale.

At present, IBAMA requires that observation of aquatic mammals be carried out during the seismic surveys turning off guns when the animals are within 500 meters of the seismic vessel (IBAMA 2003). These observations have contributed little to knowledge of cetaceans or their conservation (i.e. Gurjão et al. 2004). Although efforts have been made to standardize the monitoring procedures, results regarding the occurrence, distribution and behavior of the species observed during these surveys in Brazil have not been made widely available for the scientific community, as discussed by Parente \& Araujo (2005).

As to the species recorded during the period of this study, the consistency of the information was improved with the use of data from observations carried out during seismic surveys, to supplement the data obtained from the IWC Progress reports. The latter provide good information on the occurrence of cetaceans in Brazilian waters. The cluster analyses group the years of study into two different blocks of diversity of cetaceans similar to those shown by the analyses of seismic surveys. The first of these covering 2000 and 2001 has the lowest diversity and the other covers the years with the highest diversity.

Considering there was no reduction in effort of research during the period studied, the variation in the diversity of cetaceans seems to be influenced primarily by the number of non-resident species such as Globicephala melas, Grampus griseus and Peponocephala electra. Most of the species recorded in this study are described in specialist literature as cosmopolitan and pan-tropical species (Reeves et al. 2002). The number of coastal and resident species along the Brazilian coast is small. Sotalia guianensis and Tursiops truncatus being two examples of species with resident populations with great difference in group sizes according to latitude. Both species are found in small groups in lower latitudes. The use of indexes of diversity of cetaceans would not, therefore, be effective in verifying the influence of seismic surveys on such species in shallow waters between 0-100 meters of depth.

The main group of cetaceans that influenced the difference in diversity in this study was the Delphinidae family. Published information about this group and its reaction to seismic surveys currently only relates to two: species Delphinus delphis (Goold 1996) and Tursiops truncatus (Evans et al. 1993) and indicates that a portion of these populations moved to other areas during the seismic surveys. Another review suggests that such movements may result not exclusively as a direct effect on these species but potentially also indirectly, as a result of a decline in prey in the area being explored (Simmonds et al. 2003). Avoidance and changes in migratory routes have also been observed in other species of cetaceans, such as Physeter macrocephalus (Mate et al. 1994), Eschritius robustus (Malme et al. 1983, 1984 in Richardson et al. 1995), Balaena mysticetus (Koski \& Johnson 1987 in Richardson et al. 1995), and Megaptera novaeangliae (McCauley et al. 2000). The possible displacement of fin (Balaenoptera physalus) and sei whales (Balaenoptera borealis) is discussed in MacLeod et al. (in press).

Many other biological and oceanographic features are known to affect the diversity of species in the oceans. Here we were only able to consider data relating to seismic surveys and oceanographic parameters. The cluster analysis of the oceanographic parameters did not show similarity with the two other cluster analyses. The statistical analyses of the oceanographic data did not show significant differences in the patterns of temperature, salinity and density, and this suggest that these parameters did not influence the diversity of cetaceans in the Brazilian shelf basin during the period of study. The possibility of other environmental or anthropogenic factors having affected diversity cannot be entirely ruled out, although the only anthropogenic activity believed to have significantly changed during the period was the seismic surveys.

Considering the small amount of information available on the effects of sound pulses emitted by air-guns used in seismic surveys on the vast majority of cetacean species, and the possibility that these pulses cause avoidance and changes in migratory routes in some species of cetaceans, it is possible that the observed reduction in the diversity of cetacean during the period was brought about by the intensification in seismic surveys between 2000 and 2001.

In areas next to $22^{\circ} \mathrm{S}$ it was possible to verify a considerable increase in the number of species during periods when there are few or no seismic surveys while next to the equator this pattern was not observed. A study conducted in the mid-Atlantic Ocean between 1999 and 2000 clearly detected sound pulses from seismic surveys carried out in the northeast of Brazil, often at a distance of $3000 \mathrm{~km}$ or more from their hydrophone array (Nieukirk et al. 2004). Noting this and the analyses presented here, it is possible that the seismic surveys occurring along the whole of the Brazilian coast during 2000 and 2001 could have led non-resident species to avoid the Brazilian continental shelf. This proposition was supported by the result of the Spearman test applied in this study that showed significant negative correlation between diversity of cetaceans and means of seismic surveys.

Nevertheless, it is not possible to conclusively state that seismic surveys can directly result in reduction of diversity. The monitoring of cetaceans carried out during seismic surveys in the northeast region of Brazil between 2000 and 2001 increased information about the diversity of cetaceans. Further acoustic and bioacoustics studies of the Brazilian continental shelf as well as a program of cetacean survey should be carried out to deepen the knowledge on the dispersion of the sounds emitted during seismic surveys and the occurrence of cetaceans in the neighboring areas.

With the exception of the study conducted by Parente \& Araujo (2005), there is no previous research focusing on the relationship between seismic surveys and the diversity of cetaceans. The absence of previous data concerning variation in the diversity of cetaceans makes it impossible to compare the results found in this study and highlights the need to extend this kind of analysis to other areas of the world. These results indicate that the diversity of cetaceans has potential as a good tool for evaluating the influence of seismic surveys over large areas and for long periods. For this reason, it is recommended that a national database be built up in Brazil to monitor marine mammals during the seismic surveys in order to provide accurate information on diversity, abundance and distribution. This database would aid with research and drawing up of alternative proposals for the management of seismic surveys in such a way as to reduce impact on marine mammals.

\section{Acknowledgments}

The authors would like to thank Jotávio Gomes, the ANP geologist, for the information on seismic surveys carried out during the period under study. We also wish to express our gratitude to the ELPN-IBAMA team, in particular Edmilson Maturana, José Tadeu de Oliveira, Cristiano Vilardo and Luciane Silva. Thanks also to an anonymous referee for your contributions, the TAO Project Office and for the financial support provided by the Cetacean Society International and Comissão de Aperfeiçoamento de Pessoal do Ensino Superior (CAPES-MEC).

\section{References}

AGÊNCIA NACIONAL DO PETRÓLEO E GÁS NATURAL. 2005. Dados não-exclusivos. www.anp.gov.br. Accessed in 15 January 2005. 
DICE, L.R. 1945. Measures of the amount of ecologic association between species. Ecology, 26:297-302.

DOLMAN, S. \& SIMMONDS, M.P. 2003. Update on the impacts of acoustic pollution: with particular regard to research developments. Paper SC/55/E5 presented to Scientific Committee of the 56st International Whaling Commission.

ENGEL, M.H., MARCONDES, M.C.C., MARTINS, C.C.A., LUNA, F.O., LIMA, R.P. \& CAMPOS, A. 2004. Are seismic surveys responsible for cetacean strandings? An unusual mortality of adult Humpback whales in Abrolhos Bank, Northeastern coast of Brazil. Paper SC/56/E28 presented to Scientific Committee of the 56st International Whaling Commission.

EVANS, P.G.H., LEWIS, E.J. \& FISHER, P. 1993. A study of the possible effects of seismic testing upon cetaceans in the Irish Sea. 35 pp. Rep. from Sea Watch Foundation, Oxford, UK., for Marathon Oil UK Ltd.

GASTON, K.J., 2000. Global patterns in biodiversity, Nature, 405:220-227.

GOOLD, J.C. 1996. Acoustic assessment of populations of common dolphin Delphinus delphis in conjunction with seismic surveying. J. Mar. Biol. Ass. UK, 76:811-820.

GORDON, J., GILLESPIE, D., POTTER, J., FRANTZIS, A., SIMMONDS, A. P., SWIFT, R. \& THOMPSON, D. 2004. A review of the effects of seismic surveys on marine mammals, Mar. Technol. Soc. J., 37:16-34.

GREEN, D.M., DeFERRARI, H.A., McFADDEN, D., PEARSE, J.S., POPPER, A.X., RICHARDSON, W.J., RIDGWAY, S.H. \& TYACK, P.L. 1994. Low frequency sound and marine mammals: current knowledge and research needs. (NRC Report), National Academy Press, Washington, D.C., USA.

GURJÃO, L.M., FREITAS, J.E.P. \& ARAÚJO, D.S. 2004. Sightings of dolphins during seismic surveys on the coast of Bahia state, Brazil. LAJAM, 3(2): 171-175.

INSTITUTO BRASILEIRO DO MEIO AMBIENTE E DOS RECURSOS NATURAIS RENOVÁVEIS. 1997. Mamíferos aquáticos do Brasil: plano de ação. 80p. Edições IBAMA, Brasília, Brasil.

INSTITUTO BRASILEIRO DO MEIO AMBIENTE E DOS RECURSOS NATURAIS RENOVÁVEIS. 2001. Mamíferos aquáticos do Brasil: plano de ação, versão II. 102p. Edições IBAMA, Brasília, Brasil.

INSTITUTO BRASILEIRO DO MEIO AMBIENTE E DOS RECURSOS NATURAIS RENOVÁVEIS. 2003. Impactos da atividade de prospecção sísmica marítima. Informação ELPN/IBAMA N ${ }^{\circ}$ 012/03. Rio de Janeiro, Brasil, 66p. www.ibama.gov.br. Accessed in 12 March 2004.

INTERNATIONAL WHALE COMMISSION. 2005. Documents to download. www.iwcoffice.org/_documents/docmain.htm. Accessed in 24 May 2005.

JEFFERSON, T.A., LEATHERWOOD, S. \& WEBBER, M.A. 1994. Marine mammals of the World: FAO species identification guide. FAO/UNEP. www.fao.org/documents.html. Accessed in 25 april 2004.

LEGENDRE, P. \& LEGENDRE, L. 1998. Numerical ecology. $2^{\text {nd }}$ English edition. 853pp. Developments in Environmental Modelling, 20, Elsevier, New York

LODI, L., SICILIANO, S. \& BELLINI, C. 1996. Ocorrência e conservação da baleia-franca-do-sul, Eubalaena australis, no litoral do Brasil. Papeis Avulsos de Zoologia do Museu de Zoologia da Universidade de São Paulo, 39(17):307-328.

MACLEOD, K., SIMMONDS, M.P. \& MURRAY, E. 2006. Abundance of fin (Balaenoptera physalus) and sei whales (Balaenoptera borealis) amid oil exploration and development off northwest Scotland. J. Cetacean Res. Manage. (in press).

MADSEN, P.T., MØHL, B., NIELSEN, B.K. \& WAHLBERG. M. 2002. Male sperm whale behavior during exposures to distant seismic survey pulses. Aquat. Mammals, 28:231-240.

MATE, B.R., STAFFORD, K.M. \& LJUNGBLAD, D.K. 1994. Change in sperm whale (Physeter macrocephalus) distribution correlated to seismic surveys in the Gulf of Mexico. J. Acoust. Soc. Am., 96:3268-3269.
McCAULEY, R.D., FEWTRELL, J., DUNCAN, A.J., JENNER, C., JENNER, M.-N., PENROSE, J.D., PRINCE, R.I.T., ADHITYA, A., MURDOCH, J $\&$ McCABE, K. 2000. Marine seismic surveys: a study of environmental implications, APPEA Journal, 40:692-708.

MONTEIRO-NETO, C., ALVES-JUNIOR, T.T., ÁVILA, F.J.C., CAMPOS, A.A., COSTA, A.F., SILVA, C.P.N. \& FURTADO-NETO, M.A.A. 2000. Impact of fisheries on the tucuxi (Sotalia fluviatilis) and rough-toothed dolphin (Steno bredanensis) populations off Ceará State, northeastern Brazil. Aquat. Mammals, 26(1):49-56.

MYERS, N. 1989. Loss of biological diversity and its potential impact on agriculture and food production. In Food and Natural Resources (D. Pimentel and C.W. Hall, eds) Academic Press, San Diego, 49-68.

NIEUKIRK, S.L., STAFFORD, K.M., MELLINGER, D.K., DZIAK, R.P. \& FOX, C.G. 2004. Low-frequency whale and seismic airgun sounds recorded in the mid-Atlantic Ocean. J. Acoust. Soc. Am., 115(4):18321843.

PARENTE, C.L. \& ARAUJO, M.E. 2005. Is the diversity of cetaceans in Brazil reduced by the intensification of the seismic surveys? Paper SC/57/E6 presented to Scientific Committee of the 57st International Whaling Commission.

PINEDO, M.C., BARRETO, A.S., LAMMARDO, M.P., ANDRADE, A.L.V. \& GERACITANO, L. 2002. Northernmost records of the spectacled porpoise, Layard's beaked whale, Commerson's dolphin, and Peale's dolphin in the southwestern Atlantic Ocean. Aquat. Mammals, 28(1):32-37.

PIZZORNO, J.L.A., DORNELES, P.R., LAILSON-BRITO-JR, J., AZEVEDO, A.F., GURGEL, I.M.G.N. 1998. Additional information on humpback whale (Megaptera novaeangliae) in the southeastern Brazilian coast. Report of the International Whaling Commission, 48:443-446.

POPPER, A.X., DeFERRARI, H.A., DOLPHIN, W.F., EDDS-WALTON, P.L., GREVE, G.M., MCFADDEN, D., RHINES, P.B., RIDGWAY, S.H., SEYFARTH, R.M., SMITH, S.L. \& TYACK, P.L. 2000. Marine mammals and low frequency sound. 146pp. (NRC report), National Academy Press, Washington, D.C. USA.

REEVES, R.R.; STEWART, B.S.; CLAPHAM, P.J. \& POWELL, J.A. 2002. Guide to marine mammals of the world. Chanticleer press.

RICHARDSON, W.J., GREENE-JR, C.R., MALME, C.I. \& THOMSON, D.H. 1995. Marine Mammals and Noise. Academic Press. San Diego, California, USA.

ROHLF, F.J. \& Fisher, D.L., 1968. Test for hierarchical structure in random data sets. Systematic Zool., 17:407-412.

SHANNON, C.E. 1948. A mathematical theory of communication. Bell Syst. Tech. J., 27:379-423.

SICILIANO, S. 1994. Review of small cetaceans and fishery interactions in coastal waters of Brazil. Report of the International Whaling Commission, 15:241-250.

SILVA-JÚNIOR, J.M. 1996. Aspectos do comportamento do golfinho-rotador, Stenella longirostris (Gray, 1828), no Arquipélago de Fernando de Noronha. 131pp. Master Thesis, Universidade Federal de Pernambuco, Recife, Pernambuco, Brasil.

SIMMONDS, M.P., DOLMAN, S.J. \& WEILGART, L.S. (Eds) 2003. Oceans of noise: A WDCS scientific report. A report of the Whale and Dolphin Conservation Society. 164pp. <www.wdcs.org $>$. Accessed in 29 February 2004.

VILARDO, C., FONTANA, A., SERRÃO, M., BRAVO, L., BARBOZAFILHO, J.C.\& CAMPOS, A.N. 2003. Impactos ambientais da atividade de sísmica marítima e o licenciamento ambiental federal. Anais do VI Congresso de Ecologia do Brasil, Capítulo III: Ecossistemas aquáticos, costeiros e continentais, Fortaleza, Ceará, Brasil, 240-241.

WEITZMAN, M. 1993. What to preserve? An application of diversity theory to crane conservation, Q. Jl Econ., 108:155-183. 
Title: Diversity of cetaceans as tool in monitoring environmental impacts of seismic surveys.

Authors: Parente CL, Araújo JP e Araújo ME

Biota Neotropica, Vol.7 (number 1): 2007

http://www.biotaneotropica.org.br/v7n1/pt/abstract? taxonomic-review+bn01307012007

Data Received 09/08/06 - Revised 26/12/06 -

Accepted 21/02/06

ISSN 1676-0603 